\title{
The Oath Formulas of Matthew 23:16-22 as Evidence for a Pre-70 Date of Composition for Matthew's Gospel
}

\section{Charles L. Quarles}

Research Professor of New Testament and Biblical Theology

Charles Page Chair of Biblical Theology

Southeastern Baptist Theological Seminary

cquarles@sebts.edu

\begin{abstract}
Although several Matthean scholars have suggested that the oath formulas in Matthew 23:1622 offer evidence of a pre-70 date of composition for the Gospel, scholars have not previously conducted a thorough investigation of this claim. This essay explores the potential meaning and rationale of the oath formulas, examines post-70 Jewish conceptions of the temple site, scrutinises the oaths 'by the sanctuary' or 'by the temple' in early rabbinic literature that potentially undermine the usefulness of the oath formulas for establishing the date of the Gospel, and considers Matthew's purpose for including Matthew 23:16-22. It concludes that the oath formulas of Matthew 23 do lend credible support to a pre-70 date of composition for the Gospel of Matthew, though they cannot establish this date conclusively.
\end{abstract}

\section{Introduction}

The debate over the date of composition for the Gospel of Matthew continues and shows little sign of abating anytime soon. Although Irenaeus, who offers the earliest testimony to the date of composition, claims that Matthew wrote his Gospel in the late 50s or early 60s while 'Peter and Paul were preaching the gospel in Rome and establishing the church', ${ }^{1}$ many modern scholars, presumably the majority, date the Gospel to the period after the Fall of Jerusalem, usually in the mid-to-late 80s. ${ }^{2}$ Arguments supporting this later date of the Gospel have

1. Quoted in Eusebius, Hist. eccl. 5.8.2 (author's translation).

2. I say 'presumably' since scholars generally assert that a post-70 date is the majority position or even the 'scholarly consensus' without properly qualifying the claim and 
usually focused on Matthew 22:7 and 24:15-20 as potential post-70 reflections on the Roman siege of Jerusalem.

Other scholars have appealed to features of Matthew such as the discussion of the appropriate manner of sacrifice (Matt 5:23-24) and the payment of the temple tax (Matt 17:24-27) as evidence for a pre-70 date of composition. A few scholars have also appealed to the oath formulas in Matthew 23:16-22 as potential evidence for this earlier date. Robert Gundry's brief presentation of the argument was seminal: ${ }^{3}$

Again, why the completely unparalleled paragraph on swearing by the Temple and items associated with it (23:16-22) if Matthew wrote after the destruction of the Temple? Who could swear by it, its gold, and its altar then? Only before A.D. 70 could inclusion of such material have a very sharp point. ${ }^{4}$

Gundry's argument was convincing to R. T. France, who described Gundry's discussion of the date of Matthew as 'an instructive example of how the accepted reasoning of traditional scholarship may be challenged by a fresh approach to the data'. ${ }^{5}$ France adopted and developed this argument in his Matthew: Evangelist and Teacher:

without demonstrating that this is true by quantifying the available data. However, several recent Matthean commentators affirm or lean toward a pre-70 date. See Craig Blomberg, Matthew, NAC (Nashville: Broadman, 1992), 40-42; D. A. Carson, 'Matthew', in Matthew and Mark, rev. ed., Expositor's Bible Commentary 9 (Grand Rapids: Zondervan, 2010), 43-45; Craig Evans, Matthew, New Cambridge Bible Commentary (New York: Cambridge University Press, 2012), 4-5; R. T. France, The Gospel of Matthew, NICNT (Grand Rapids: Eerdmans, 2007), 19; Jeffrey Gibbs, Matthew 1:1-11:1, Concordia Commentary (St Louis: Concordia, 2006), 6466; Donald Hagner, Matthew 1-13, WBC 33a (Dallas: Word, 1993), lxxiii-lxxvii; Gerhard Maier, Das Evangelium des Matthäus: Kapitel 1-14, HTA (Witten: SCM, 2015), 17-20; John Nolland, The Gospel of Matthew, NIGTC (Grand Rapids: Eerdmans, 2005), 12; Grant Osborne, Matthew, ZECNT (Grand Rapids: Zondervan, 2010), 33-35; and Charles Quarles, Matthew, Exegetical Guide to the Greek New Testament (Nashville: B\&H, 2017), 4.

3. Several of Gundry's arguments for a pre-70 date for Matthew appeared earlier in J. A. T. Robinson, Redating the New Testament (London: SCM, 1976), 103-106. However, although Robinson argued that 'Matthew is more concerned than any other evangelist with the relationship of Christianity to the temple, the priesthood and the sacrifices' (104), he did not specifically refer to 23:16-22 as evidence for this concern.

4. Robert Gundry, Matthew: A Commentary on His Handbook for a Mixed Church under Persecution, 2nd ed. (Grand Rapids: Eerdmans, 1994), 604. Gundry further argued that Matt 23:16-22 was a Matthean composition due to its parallelism, allusion to the OT, polemic character, and vocabulary, 'all traits of Matthew's composition'.

5. R. T. France, Matthew: Teacher and Evangelist (Downers Grove: IVP, 1980), 89 n16. 
Matthew records Jesus' instructions to his disciples on the right attitude in which to present an offering in the temple (5:23-24) and on oaths focusing on the temple and its ritual (23:16-22). At the time when Jesus taught this was of course entirely appropriate, and it is quite possible that Matthew has simply recorded Jesus' teaching for its own sake, leaving it to his readers to draw from it principles which they could use in a situation where the teaching no longer had a literal application. But at least it may be claimed that to include such sayings in Matthew's presumably selective account would make more immediately relevant sense in the period when the temple was still standing. ${ }^{6}$

Few scholars who prefer a post-70 date for Matthew have critiqued this specific element of Gundry's and France's case for a pre-70 date. However, Davies and Allison briefly explained why they did not find the argument convincing:

Some have imagined that the present tenses with regard to the temple would be more immediately relevant if Matthew had been written before AD 70, others that at least the tradition behind 23.16ff. must have been formulated before the temple's destruction (see n. 43). But post-70 Jewish literature is filled with such present tenses. The temple remained a literary and theological reality long after it physically ceased to be. The eternal Torah is filled with immutable laws about the temple; and those laws remain to be pondered and discussed notwithstanding all historical contingencies. ${ }^{7}$

This objection seems to miss the primary point of the argument. Neither Gundry nor France disputes that the temple continued to be pondered and discussed in post-70 Judaism (or Christianity for that matter). Instead, France cautiously and Gundry more forcefully challenged the likelihood that Jews would swear by (not ponder, discuss) sacrifices no longer offered, gold now pillaged, an altar that had crumbled, and a temple reduced to ash and rubble. They allow for theoretical, theological, and historical discussions related to the temple. They doubt or deny Jewish practices would continue after $\mathrm{AD} 70$, just as if the temple and its accoutrements still stood.

The discussions of the relevance of the oaths of Matthew 23 for dating the Gospel thus far have been very brief statements consisting of only a paragraph or less, not thorough analyses. Although they introduced a promising line of enquiry, they have not determined the meaning and rationale of the oath formulas that appear there, explored post-70 Jewish conceptions of the temple site, examined

6. France, Matthew: Teacher and Evangelist, 88.

7. W. D. Davies and Dale Allison, Matthew, 3 vols, ICC (Edinburgh: T\&T Clark, 19881997), 3:293. 
the oaths 'by the sanctuary' or 'by the temple' in early rabbinic literature that appear to contradict their claim, or adequately treated Matthew's purpose for including 23:16-22. This essay will proceed with these enquiries and will conclude that the oath formulas of Matthew 23 do support, though they do not prove conclusively, a pre-70 date of composition for the Gospel of Matthew.

\section{The Meaning and Rationale of the Oath Formulas}

What did the formulas of Matthew 23:16-22 mean and on what grounds did the scribes distinguish them as binding or non-binding? Various scholars have suggested that these oath formulas may be explained as oaths of forfeiture, solemn oaths, or qorban vows. ${ }^{8}$ Scholars debate which of these categories best explains the distinctions challenged and dismissed by Jesus. Unfortunately, the debate has not reached any formal resolution, as the issues involved are complex.

Robert Gundry has argued that the oaths in Matthew 23:16-22 are oaths of forfeiture. He suggested that the rabbinic distinction between binding and nonbinding oaths was based on the rationale that one might swear only by an object that was subject to seizure if the oath was broken. ${ }^{9}$ In Gundry's view, the oath formula apparently meant 'May I forfeit such and such to you, if I do not keep my oath.' Since the person taking the oath had no claim to ownership of the temple or the altar, an oath by the temple or altar was meaningless. Since a sacrifice placed on the altar or a monetary offering to the temple was subject to forfeiture, oaths by the gift and the gold were binding.

This view faces significant obstacles. Not only does Gundry cite no literary evidence in its support, but it is also doubtful that a gift placed on the altar could be retrieved by the offeror at that point and submitted to the one to whom the oath had been made. The rabbis generally refrained from removing an appropriate offering from the altar even if it was ritually unclean (m. Zevah. 9:2-4; b. Zevah. $84 a-85 b)$. The general principle was 'Whatever is appropriate to the altar if it has gone up [to the altar], should not go down.' The reference to the gold of the temple poses a similar problem. The expression 'gold of the temple' probably refers to gold that belongs to the temple, not gold that is merely deposited for safe-keeping

8. For discussions of oath formulas in the Hebrew Bible, see Blane Conklin, Oath Formulas in Biblical Hebrew, LSAWS 5 (Winona Lake, Indiana: Eisenbrauns, 2011), https:// doi.org/10.5325/j.ctv1bxgzws; Yael Ziegler, 'So Shall God Do: Variants of an Oath Formula and Its Literary Meaning', JBL 126 (2007): 59-81, https://doi.org/10.2307/27638420.

9. Gundry, Matthew, 463. This explanation was later adopted by Blomberg, Matthew, 345, and, with greater hesitation, by Craig Keener, A Commentary on the Gospel of Matthew (Grand Rapids: Eerdmans, 1999), 549. 
in the temple and that could be later retrieved by the owner. This gold probably refers to the gold that adorned the temple, its furniture, and its implements, as well as gold coins reserved for temple use (Josephus, J.W. 5.201-227; 6.387-391; Ant. 14.105-109). The shekels paid to the temple were required to be silver (e.g. Lev $5: 15 ; 27: 3) .{ }^{10}$ However, gold coins were contributed to the temple as gifts or as surcharges related to the shekel offering so that these could be melted down and used to gild objects in the temple ( $\mathrm{m}$. Sheqal. 6:5) or to make patches for repairing damaged gilding of the temple structure (y. Sheqal. 1:4; b. Menah. 108a). Even if this gold refers to the offerings of worshippers, it appears to have already been given to the temple and, as Jesus insisted, set apart for God's use ('sanctified'). It is doubtful that it could be retrieved even by the one who donated it. ${ }^{11}$

The oaths 'by the Temple' and 'by heaven' in Matthew 23:20-22 more likely belong to the category of the solemn oath in which the swearer used a sanctified object as a substitute for the divine name in oaths that were equivalent to 'I swear to God' or 'As God is my witness'. ${ }^{12}$ In the LXX, such appeals normally used the accusative case,$^{13}$ the preposition $k \alpha \tau \alpha$ with the genitive, ${ }^{14}$ or the bare dative. ${ }^{15}$ Judges 21:7, 1 Samuel 24:22, 2 Samuel 19:8, 1 Kings 1:17, 2 Kings 2:8, and 2 Chronicles 15:14 use the formula Év kupí $\omega$, a construction that is likely equivalent to the formula 'as the Lord lives' (Judg 8:19; 1 Sam 19:6; 28:18; 1 Kgs 1:29; Jer 4:2; $5: 2 ; 12: 16 ; 45: 16)$. This formula most closely approximates the grammatical form of the oaths in Matthew 23:16-22.

10. The priests required that the temple tax be paid in the form of Tyrian shekels $(\mathrm{m}$. Bek. 8:7) because the Judean mints were permitted to make coins only in bronze or copper while under Roman rule, but the Tyrian mint still produced the mandatory silver coins. Jerome Murphy-O'Connor, 'Jesus and the Money Changers (Mark 1:15-17; John 2:13-17)', RB 107 (2000): 42-55. See also Peter Richardson, 'Why Turn the Tables? Jesus' Protest in the Temple Precincts', in Society of Biblical Literature 2001 Seminar Papers (SBLSP 31; Atlanta: Scholars, 1991), 507-523; Arye Ben-David, Jerusalem und Tyros. Ein Beitrag zur palästinischen Münz- und Wirtschaftsgeschichte (126 a.C.-37 p.C) (Basel: Mohr, 1969).

11. The probable reason for the funnel-shaped receptacles of the thirteen shofar chests in the temple was to facilitate giving and to prevent removal of the shekels dropped into the chest (m. Sheqal. $2: 1 ; 6: 1,5$ ).

12. For this latter sense, see especially 1 Sam $20: 42$.

13. Josh 1:6; 2:12; 9:18; Prov 30:9; Hos 4:15; Isa 65:16; Dan 12:7; Bel 7.

14. Gen 22:16; 31:53; Exod 32:13; Deut 9:27; 1 Sam 30:15; 1 Kgs 2:23; Amos 4:2; 6:8; 8:7,14; Zeph 1:5 (2x); Isa 45:23; 62:8; Jer 22:5; 28:14; 30:7. Cf. Heb 6:13.

15. Deut 10:20; Zech 5:4; Mal 3:5; Isa 19:18; 48:1; Jer 51:26. In Deut 32:40 / Odes 2:40, the dative marked the hand raised in the taking of the oath (see the similar use of kató with the genitive in Isa 62:8). However, the dative normally identified the party to whom the oath was made (Ps 131:2). 
Binding oaths of this nature required approved reverent substitutions for the divine name. ${ }^{16}$ Jesus insists that the one who swears by the temple swears by it and the one who dwells in it, i.e. the God of Israel. Similarly, one who swears by the temple swears by the throne of God and the one who occupies that throne. Thus, Jesus's rebuttal of the casuistry of the scribes explicitly addresses the concern for appropriate substitutions for a direct reference to God in these specific oath formulas.

But why would the scribes and Pharisees whom Jesus rebukes assume that a reference to the temple was not an appropriate substitution for the divine name? Several commentators suggest that Babylonian Nedarim 14a hints at the rationale. ${ }^{17}$ The rabbis argued that if one swore by the Torah, the oath meant nothing. However, if one swore by what is written in the Torah, then the oath was binding. The following discussion explicitly states the basis for the distinction. By the 'Torah' one might mean merely the parchment that composed the scroll. 'What is written in the Torah' referred to the text of the Torah, which included the divine name and was thus an acceptable substitute for the divine name in an oath. Similarly, the rabbis may have distinguished between the temple as a mere building made of limestone block and the Shekhina that resided within it. The Palestinian Talmud records Rabbi Jehudah's opinion that the oath 'May it be to me like Jerusalem' was an oath 'that did not say anything, since this one intended to refer only to its wood and stones' (y. Ned. 1:3). It would not be surprising if this same line of reasoning eliminated the temple and altar as appropriate substitutions for the divine name as well for the scribes of Jesus's day. This explanation is not entirely satisfactory. Although it provides grounds for an argument against using the temple as a substitution for the divine name, it does not explain why the gift on the altar or the gold of the temple would be seen by the rabbis as appropriate substitutes.

Samuel Lieberman has argued that the principle underlying the distinctions between the binding and non-binding oaths in Matthew 23:16-19 relates to the law of qorban. ${ }^{18}$ The Mishnah stated:

16. m. Shevu. 4:13; b. Shevu. 35a-b.

17. France, The Gospel of Matthew, 871; Davies and Allison, Matthew, 3:291.

18. Saul Lieberman, Greek in Jewish Palestine: Studies in the Life and Manners of Jewish Palestine in the II-IV Centuries CE (New York: Jewish Theological Seminary of America, 1942), 130-138, esp. 134. His view was largely adopted by David Garland (The Intention of Matthew 23, NovTSup 51 (Leiden: Brill, 1979), 134-135) and Kenneth Newport (The Sources and Sitz im Leben of Matthew 23, JSNTSup 117 (Sheffield: Sheffield Academic, 1995), 100-102). 
[If he said, 'May it be to me] like the lamb [of the daily whole offering]', 'Like the [temple] sheds', 'Like the wood', 'Like the fire', 'Like the altar', 'Like the sanctuary', 'Like Jerusalem' - [if] he vowed by the name of one of any of the utensils used for the altar, even though he has not used the word qorban - lo, this one has vowed [in a binding way as if he had vowed] by qorban. R. Judah says, 'He who says, 'Jerusalem', has said nothing.'19

The sages' declaration affirmed that a vow of qorban was binding (even if the swearer did not explicitly use the word qorban) if the swearer substituted a reference to an object wholly dedicated to God. David Garland concluded: 'The Temple gold and the altar gift were binding as part of an oath because they were connected with the term Korban, while the Temple and the altar, though holy objects, were illegitimate substitutes in an oath formula.' ${ }^{20}$

However, this interpretation appears to contradict what the sages of the Mishnah explicitly stated. Although the scribes of Matthew 23:16-19 argued that vows by the sanctuary and altar were not valid, the sages of the Mishnah argued that the expressions 'may it be like' the sanctuary, the altar, and even the city of Jerusalem were proper substitutions for a direct reference to qorban and thus valid. Although rabbi Judah may initially seem to be a dissenting voice, he is only adding a qualification that the comparative particle must be included in the vow formula. Otherwise, the vow formula made a nonsensical pronouncement that did not qualify as binding. ${ }^{21}$ In the discussion of formulas in the Mishnah, the various objects discussed in the passage quoted above were all entirely devoted to God; thus to say 'May it be to me like [one of these specific objects]' functioned as a vow to abstain from the use of a particular object since it was to be treated as something wholly devoted to God and not for ordinary use. ${ }^{22}$

The most reasonable explanation for the difference between the scribal views in Matthew 23:16-19 and the Mishnaic view was recently suggested by David

19. m. Ned. 1:3 (Neusner). Cf. t. Ned. 1:3; y. Ned. 1:3; Gen. Rab. 56.

20. Garland, Intention of Matthew 23, 135.

21. See Herbert Danby, The Mishnah (Oxford: Oxford University Press, 1933), 264 n16. For other examples of nonsensical vows 'made in error', see m. Ned. 9:10. One may object that Garland's explanation overlooks the fact that vows, bans, and oaths are each being discussed in turn in the Mishnaic tractate, and this section of the discussion relates specifically to the qorban vow rather than to oaths. Note, however, that the distinction between oaths and qorban vows is sometimes blurred (b. Shev. 22a). The word qorban was used in vows and oaths in a variety of ways. Qorban is defined in the Mishnah as a vow to bring a sacrifice' (m. Ned. 1:2).

22. See, for example, b. Ned. $11 \mathrm{~b}$ in which the vow 'For a qorban shall be what I eat with you' is interpreted as 'Let your food be for an offering, therefore I will not eat of your food.' See also Josephus, Ag. Ap. 1.167 in which qorban is defined as 'a thing devoted to God'. 
Instone-Brewer. ${ }^{23} \mathrm{He}$ argues that the distinctions are a product of development in the rabbinic view. ${ }^{24}$ In the first stage, the rabbis approved the objects that were offered as sacrifice or offered up together with the sacrifice as appropriate substitutions for a direct reference to qorban. These included the sacrificial lamb, the sheds where the sacrificial animals were kept and from which the sacrifices were taken, the wood consumed with the burnt offering, and even the sacrificial fire..$^{25}$ In the second stage, locations sanctified by the offerings were accepted as substitutes. These included the altar, the sanctuary, and Jerusalem. In y. Ned. 1:3, r. Simeon b. Laqish explains the rationale for these approved substitutions. 'Altar' is a shortened reference to 'the offering of the altar'. 'Sanctuary' is a shortened reference to 'the offering of the sanctuary'. Instone-Brewer observes 'The logic is therefore still that only offerings can act as substitutes for "qorban". ${ }^{26}$ In the third stage, the temple utensils that were used in the act of sacrifice and thus sanctified by the offering were also approved substitutions for qorban. The fourth stage relates to qualifications regarding oaths sworn by 'Jerusalem' which resulted in a ruling by $r$. Judah around $150 \mathrm{CE}$.

Instone-Brewer argues that the stages of the development of the tradition proceed from approving objects most closely associated with the offering to those more remotely associated. He posits that the debate in Matthew 23:16-22 occurs in the phase between the first and second stages of the development of the rabbinic tradition. He concludes that 'Matthew's account coheres in detail with the development of these rulings as preserved in rabbinic traditions' and that Matthew's discussion 'could certainly fit into the period before $70 \mathrm{CE}$ '. ${ }^{27}$

Thus, the distinctions in the validity of various oath formulas addressed in Matthew 23:16-20 relates to approved substitutions for qorban. In Matthew 23:2122 , Jesus counters the arguments of the scribes by appealing to the principles of

23. One should not assume that the lack of parallels in Second Temple and rabbinic literature to the specific view of oaths described in the indictment of the scribes and Pharisees in Matthew implies that these distinct categories were invented by Jesus or Matthew. The lack of parallels may merely suggest that Jesus's followers' position on the binding nature of these oaths prevailed and led to a change in the rabbinic assessment of legitimate vow formulas or that the rabbinic view developed based on other considerations.

24. David Instone-Brewer, 'Qorban in Mat. 23.16-20 \& m. Ned. 1.3', Rabbinic Traditions, https://rabbinictraditions.blogspot.com/2020/11/qorban-in-mat2316-20-mned13.html. I am grateful to Instone-Brewer for kindly and helpfully corresponding with me about various aspects of my research.

25. Instone-Brewer ('Qorban') notes that y. Ned. 1:3 states that r. Yohanan even included the 'smoke' that rose up from the altar together with the fire.

26. Instone-Brewer, 'Qorban'.

27. Instone-Brewer, 'Qorban'. 
the 'solemn oath'. He argues that although the scribes of the early first century may not recognise the temple or heaven as approved substitutions for qorban, they should recognise these as approved substitutions for the divine name.

\section{The Improbability of Swearing by the Temple after the Temple's Destruction}

Would Jesus's teaching regarding oath formulas in Matthew 23 have been meaningful and persuasive in the era after the destruction of the temple? Would the association between the rubble and ashes of the temple and the presence of Yahweh have been strong enough for a reference to the temple to continue to qualify as a reverent reference to God himself? ${ }^{28}$

Jewish theologians held starkly different views of the relationship of the divine presence to the temple after its destruction. Those who wrote or taught in the immediate aftermath of the destruction insisted that God's presence had abandoned the sanctuary. Josephus argued that God's presence abandoned Jerusalem and the temple prior to the Roman destruction. After describing how the temple was polluted by the brigands who overran it, Josephus mused: 'For thou [temple] wert no longer God's place, nor couldst thou survive after becoming a sepulcher for the bodies of thine own children and converting the sanctuary into a charnel-house of civil war.'29

In his speech calling for the surrender of Jerusalem, Josephus exclaimed: 'My belief, therefore, is that the Deity has fled from the holy places and taken His stand on the side of those with whom you are now at war.' ${ }^{30}$ He later added: 'God it is then, God Himself, who with the Romans is bringing the fire to purge His temple and exterminating a city so laden with pollutions. ${ }^{31}$

28. For discussions of Matthew's complex view of the temple, see Daniel Gurtner, 'Matthew's Theology of the Temple and the "Parting of the Ways": Christian Origins of the First Gospel', in Built upon the Rock: Studies in the Gospel of Matthew, ed. Daniel Gurtner and John Nolland (Grand Rapids: Eerdmans, 2008), 128-153; Akiva Cohen, 'Matthew and the Temple', in Matthew within Judaism: Israel and the Nations in the First Gospel, ed. Anders Runesson and Daniel Gurtner, ECL 27 (Atlanta: SBL, 2020), 75-100, https://doi.org/10.2307/j. ctv13qfv9z.8.

29. Josephus, J.W. 5.19. All quotations from Josephus are from Thackeray's LCL vols.

30. Josephus, J.W. 5.412. He summarised his speech with the insistence that 'you are warring not against the Romans only, but also against God' (J.W. 5.378). In 4.104, he argued that God preserved John, the leader of the brigands who later controlled Jerusalem and the temple, 'to bring ruin upon Jerusalem'.

31. Josephus, J.W. 6.110. 
Josephus claims that the notion that God abandoned and destroyed the temple was affirmed by others, Romans and Jewish zealots alike. Titus argues that the God who once inhabited the temple had abandoned it: 'Why do you defile your temple with the blood of foreigner and native? I call the gods of my fathers to witness and any deity that once watched over this place - for I now believe there is none ...' ${ }^{32}$

In his speech that inspired the mass suicide at Masada, Eleazar insisted that God ordained and caused the Roman destruction. ${ }^{33}$ He insisted that it was not the military might of the Romans that brought about their victory because "the intervention of some more powerful cause has afforded them the semblance of victory'. ${ }^{34}$ Eleazar cried:

Where now is that great city, the mother-city of the whole Jewish race? ... What has become of her that was believed to have God for her founder? Uprooted from her base she has been swept away, and the sole memorial of her remaining is that of the slain still quartered in her ruins! Hapless old men sit beside the ashes of the shrine and a few women, reserved by the enemy for basest outrage ... Nay, I would that we had all been dead ere ever we saw that holy city razed by an enemy's hands, that sacred sanctuary so profanely uprooted! ${ }^{35}$

According to Josephus, the Jewish leaders of besieged Jerusalem responded to Titus's pleas for them to surrender to avoid the destruction of their city and their temple by claiming that they 'were unconcerned for their native place, and that the world was a better temple for God than this one [the Jerusalem temple]'. ${ }^{36}$

Rabbis such as Johanan b. Zakkai (late first century), Jonathan (the second century), Zavdai b. Levi (the third century), and Samuel bar Nahman (the third century) taught that the Shekhina departed from the temple and returned to the heavenly dwelling place when the temple was destroyed. ${ }^{37}$ Rabbi Akiva and his

32. Josephus, J.W. 6.126-127.

33. Josephus, J.W. 7.359-361.

34. Josephus, J.W. 7.360 .

35. Josephus, J.W. 7.375-379. Josephus describes those who died of starvation during the siege of Jerusalem: 'Each victim expired with his eyes fixed on the temple' (J.W. 5.517).

36. Josephus, J.W. 5.458 .

37. Ephraim Urbach, The Sages: Their Concepts and Beliefs, 2 vols (Jerusalem: Magnes, 1987), vol. 1, 54-57. Many references describe God's abandonment of the temple at its first destruction. However, the same views would seem to apply to the destruction of the second temple as well. 
followers argued that the Shekhina went with the Israelites into their places of exile and would not return until the people returned or the end came. ${ }^{38}$

Some Jews anticipated the rebuilding of the city, the temple, and the altar. ${ }^{39}$ They also prayed for the rebuilding of the House of God (m. Tamid. 7:3; m. Pesah. 10:6; m. Ta'an. 4:8; m. Avot 5:20). But this yearning for reconstruction was driven in part by the conviction that the presence of God had departed with the temple's destruction.

On the other hand, some rabbis did claim that the glory of God still resided at the former site of the Jerusalem temple. However, this tradition seems to have arisen significantly later. At the end of the third century, Eleazar b. Pedat said, 'Whether the temple is destroyed or not, the Shekhina does not stir from its place. ${ }^{40}$ At the end of the fourth century, Amora r. Aha interpreted Song 2:9 to assert that the Shekhina would never leave the western wall of the temple. ${ }^{41}$ And r. Joshua stated:

I have heard that sacrifices may be offered up although there is no temple, and that the most holy offerings may be eaten although there are no curtains, the lesser holy offerings and the second tithe although there is no wall, for the sanctity of the First Temple availed for its own time and for the future. ${ }^{42}$

But no evidence suggests that this later assessment of the sanctity of the temple site was affirmed in the late first century when Matthew, according to the prevailing view, composed his Gospel. The earlier evidence suggests that God's presence was not closely enough associated with the site of the destroyed temple for an oath 'by the temple' to have remained valid or meaningful. The view that God had abandoned his temple before its destruction would seem to prevent the practice of continuing to swear by the temple after AD 70.

\section{Evidence that Jews Generally Ceased Swearing by the Temple after Its Destruction}

This hypothesis must be tested by consulting early rabbinic literature to see if Jews continued to swear by the temple after its destruction. Certainly, the rabbis

38. Urbach, The Sages, 1:55-56. See b. Yoma. 56b and esp. b. Meg. 29a.

39. m. Ma'as. 5:2; b. Ber. 44 a.

40. Urbach, The Sages, 1:57. See Midr. Psalms 10.3.

41. Urbach, The Sages, 1:57. See Cant. Rab. 2.9.

42. Urbach, The Sages, 1:57. See m. Ed. 8:6. Philo insisted that while the temple was standing, God 'does not permit those who desire to perform sacrifices in their own houses' (Spec. Laws 1.68). 
continued to discuss vows and oaths invoking the temple (t. Ketub. 3:2; t. Ker. 4:4). But such discussions do not necessarily relate to current Jewish practice during this period. Rabbinic literature is filled with discussions of topics that did not relate to contemporary Jewish practice in the aftermath of the temple's demise. Entire Mishnaic tractates discuss topics such as various offerings for the temple, the Day of Atonement, and the different animal sacrifices, which had little direct practical relevance for the rabbis and their contemporaries when the temple no longer stood and its rituals could not be enacted. ${ }^{43}$ The rabbis of the Talmuds also comment extensively on rabbinic rulings pertaining to these matters in the Gemara, even though centuries had passed since the temple's destruction.

One could argue that the discussion in Matthew 23:16-22 is of the same nature and at a purely theoretical level. The members of the Matthean community were being armed to best their opponents from local synagogues in a debate about topics that would not impact their own conduct or that of their opponents. Although this is possible, a debate of a purely theoretical level is out of place in Matthew 23. Matthew 23:3 introduced the discourse with a focus on what the two different groups 'observe' and 'practise'. The matters addressed are as practical as how one wears phylacteries and tassels, the titles used of members of the group, tithing, and cleaning vessels. The teaching regarding vows is likely included because it impacts actual practice as well.

To determine if the oath formulas of Matthew 23 may be valuable for narrowing the possible range of dates for the composition of Matthew, the critical question is not if the oath formulas of Matthew 23 were still being discussed in Judaism; it is rather if the oath formulas that relate to the temple were still being used in Judaism particularly in the decades immediately following the temple's destruction.

The Tannaitic period (c. AD 10-220) is usually divided into five or six generations with the following approximate dates: first generation (AD 10-80); second generation (AD 80-120); third generation (AD 120-140); fourth generation (AD 140-165); fifth generation (AD 165-200); and sixth generation (AD 200-220). The divisions between these generations are not neat and clean, and a single

43. Akiva Cohen has correctly observed: 'The discussion in almost every mishnah, chapter, and tractate of the Mishnah, is either directly, or indirectly, associated with and grounded in Israel's temple-based cult. Thus we may safely say that the symbolic significance of the Jerusalem temple, even when it is no longer standing, continues as the symbolic center of the Mishnah' (italics original). Akiva Cohen, Matthew and the Mishnah: Redefining Identity and Ethos in the Shadow of the Second Temple's Destruction, WUNT 418 (Tübingen: Mohr Siebeck, 2016), 400, https://doi.org/10.1628/978-3-16-154810-9. 
rabbi may be active in more than one generation. Nevertheless, these generations assist in providing approximate timeframes for the sayings and activities of many of the rabbis. ${ }^{44}$ The Mishnah preserves three oaths in which a figure swore 'by this Temple' (הַפְעעוֹן הַזְה - hamma'on hazeh).

Mishnah Keritot 6:3 records the oath of Baba b. Buti who swore 'By this Temple!' that, if he were allowed to do so, he would offer his own suspensive guilt offering (Lev 5:17-19) called 'the guilt offering of the pious' every day, including the day after the Day of Atonement. Baba b. Buti belonged to the pre-Tannaitic period (c. $200 \mathrm{BC}$ to AD 10), decades before the temple's destruction. The pre-70 date of the oath is confirmed by the details that the guilt offerings are still being given, and the rituals of the Day of Atonement, during which the ordinary guilt offering was suspended, are still being observed.

Mishnah Keritot 1:7 says that Simeon b. Gamaliel swore 'By this sanctuary! I shall not rest tonight until they [the pair of birds required for the cleansing of a woman after childbirth (Lev 12:6)] shall be at [silver] denars. ${ }^{45}$ Although two different men of two different eras are named Simeon b. Gamaliel in the Mishnah, this is clearly a reference to Simeon b. Gamaliel I, who belonged to the first-generation Tannaim (c. AD 10-80) rather than to Simeon b. Gamaliel II, who belonged to the fourth generation (c. AD 140-165). The unreasonably high cost of the pair of birds was an urgent concern to Simeon because the temple still stood, and the burnt offering and sin offering required by Leviticus 12:6-8 were still being presented to the LORD by the priest for the atonement and cleansing of the new mother.

A more difficult case is Mishnah Ketubbot 2:9. The verse discusses the principle that a priest may not testify on his own behalf when testifying to the purity of his wife (whom Lev 21:13-14 and Ezek 44:22 required to be a virgin) after a town had been overrun by invaders (who often raped the Jewish women). ${ }^{46}$ Priests who continued to have sexual relationships with a wife who had been (potentially) defiled in this manner were to be punished by flogging (b. Yevam. 56b). Zechariah b. Haqqasab argues that his wife's purity is beyond suspicion. He swears 'by the Temple' that he never released his wife's hand the entire time that

44. See Danby's helpful Appendix 3 in Mishnah, 799-800.

45. The price had recently climbed to a gold denar that was worth approximately twenty-five times the value of a silver denar. See Danby, Mishnah, 564 n7.

46. A rape would disqualify the woman from continuing to have sexual relations with her husband. 
the Gentiles occupied Jerusalem, so he could be completely confident that no pillager had raped her. ${ }^{47}$

Zechariah belonged to the first generation of Tannaim (c. AD 10-80). ${ }^{48}$ Thus, his oath may hypothetically precede or soon follow the destruction of the temple. But both grammatical and historical considerations seem to suggest the former. The use of the demonstrative pronoun in the expression 'this temple' (הַפְעוֹן הַזָזה - hamma'on hazeh) seems to indicate that Zechariah swore by a temple that still stood and to which he could point as he took his oath.

Unfortunately, our extant sources do not enable us to identify precisely and with complete confidence the historical context in which Zechariah made his oath, i.e. which Gentile occupation of Jerusalem was in view. However, it is highly unlikely that the Gentile invasion of the city is that of AD 70, associated with the destruction of the temple. Josephus states that, in the aftermath of that invasion, the surviving Jews were sold into slavery if they were under the age of seventeen. Older Jews were sentenced to labour in the mines of Egypt or were handed over to the provinces to entertain the masses in the Roman theatres by being slain by gladiators or devoured by wild beasts. ${ }^{49}$ In his speech at Masada, Eleazar claimed that the Romans kept some of the women at the ruins of the temple 'reserved by the enemy for basest outrage'..$^{50}$ Apparently, the Romans mocked the holy site by forcing the women to act as the temple prostitutes of pagan religion. Obviously, none of these scenarios allows for a situation in which Zechariah can appear before fellow-priests or sages to plead for the right to have intimate relationships with his wife without penalty.

More likely, the Gentile occupation of Jerusalem was led by Florus ${ }^{51}$ in early June of AD 66, during which 3,600 Jewish men, women, children, and even infants were massacred and many homes were pillaged. This was an event that Josephus describes as an expression of 'the unprecedented character of the Roman's cruelty'. ${ }^{52}$ The term that Josephus used to describe the pillage of the city probably includes rape, and this is especially likely since Josephus says that the Romans

47. Sadly, despite his oath, Zechariah's testimony was deemed invalid since 'no one can testify in his own behalf'. Thus his wife was 'forbidden to her husband' (m. Ket. 2:9).

48. Danby, Mishnah, 799. However, m. Ed. 8:2 suggests that Zechariah was a contemporary of Jose the Priest, one of the second-generation Tannaim (c. AD 80-120), which indicates that either Zechariah was still active early in the second generation or that Jose was active late in the first generation.

49. Josephus, J.W. 6.414-419.

50. Josephus, J.W. 7.377.

51. Josephus, J.W. 2.293-332.

52. Josephus, J.W. 2.308. 
engaged in 'every variety of pillage'. ${ }^{53}$ In such circumstances, the scenario in Mishnah Ketubbot 2:9 would make perfect sense. Zechariah would need to prove that his wife had not been touched by the pillagers. After the Roman withdrawal, he would have the opportunity to be with his wife. And he would continue to be active for years in his priestly functions.

The brief occupation of a portion of Jerusalem by Cestius and his troops in November of 66 is another good option. ${ }^{54}$ Josephus states that after the 'catastrophe of Cestius many distinguished Jews abandoned the city as swimmers desert a sinking ship'. ${ }^{55}$ If Zechariah and his wife fled Jerusalem at that time, they could have remained together and may have needed to defend the wife's purity and the legitimacy of their ongoing sexual unions.

Furthermore, the invasion of the city by the Idumaeans could be the Gentile invasion that exposed Zechariah's wife to potential rape since the Idumaeans 'turned to the city, looting every house and killing all who fell in their way'. ${ }^{56}$ After the Idumaeans' withdrawal from the city, any who could afford to pay a bribe to the Zealot guards of the city deserted to the Romans in order to save their lives. ${ }^{57}$

Even later, some Jews were able to evacuate from the city and thus avoided the horrors that befell the people after the devastation of Jerusalem. However, these evacuations are associated with the Roman siege of Jerusalem, not a Roman occupation. In the early stages of the Roman siege, after Josephus appealed to the Jews of Jerusalem to surrender, Titus permitted all who deserted to go free..$^{58}$ Then, in the final stages of the siege, immediately before the destruction of the temple, the chief priests and many of the aristocracy deserted the city. Caesar treated them kindly and sent them to nearby Jufna with the promise that he would restore their property after the war. ${ }^{59}$

Any of the Gentile occupations of Jerusalem that preceded (some by years) the destruction of the temple better fit the circumstances related to Zechariah's oath than the final Roman occupation of the city that resulted in the temple's destruction. A scenario in which Zechariah b. Haqqasab must debate the purity of his wife despite the Gentile occupation of Jerusalem in order to continue having

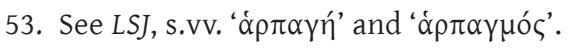

54. Josephus, J.W. 2.527-545.

55. Josephus, J.W. 2.556.

56. Josephus, J.W. 4.314.

57. Josephus, J.W. 4.377-379.

58. Josephus, J.W. 5.420-423. These smuggled out gold coins by swallowing them so they would have the resources to survive and begin a new life elsewhere in Israel.

59. Josephus, J.W. 6.113-120. 
sexual relationships with her without fear of being flogged by fellow Jews does not comport well with Josephus's description of the separation of families and harsh treatment by the Romans that occurred in the aftermath of the destruction of the temple. Furthermore, the Tosefta explains that when the sages prohibited Zechariah from remaining with his wife 'He set aside a house for her by herself. She was supported by his property. But he never was alone with her except in the presence of her children' (t. Ketub. 3:2). The Tosefta describes a situation in which the family remained intact, and this sounds unlike the experience of the Jews of Jerusalem immediately after the war with Rome. Thus, despite the difficulties in dating precisely the oath of Zechariah, the oath was most likely made while the temple still stood.

An examination of oath formulas in the Tosefta, Jerusalem Talmud, and Babylonian Talmud confirms what the evidence of the Mishnah suggests - that the practice of taking an oath by the temple was very rare after AD 70. Although several English translations of the Talmud ${ }^{60}$ portray individuals such as r. Hiyya, Bar Qappara, Eliezer of Birta, and Akiva as swearing 'by the Temple!', the oath formula refers to the act of divine worship, not the temple structure itself. Marcus Jastrow suggests that the Aramaic expression העבודה (h'vodah) in these oath formulas means 'by the worship!', which serves as a substitute for 'By God!'61 When English versions translate the Aramaic expression more precisely, they usually prefer 'by the Temple service', ${ }^{62}$ although a reference to the temple is not explicit in the expression. This oath formula seems to serve as a replacement for the earlier expression 'by the temple'. The table below lists occurrences of the formula in early rabbinic halakah, the speaker who used the formula, and the approximate time frame in which it was used. ${ }^{63}$

60. These include both the Soncino edition and Neusner's edition. Neusner's edition prefers the translation 'by the temple service' but does not employ this translation consistently.

61. Marcus Jastrow, A Dictionary of the Targumim, the Talmud Babli and Yerushalmi, and the Midrashic Literature with an Index of Scriptural Quotations (London: Luzac; New York: G. P. Putnam's Sons, 1903), s.v. 'עִ עִבוֹדָה'. Jastrow shows that the term may refer to work in general, manual labour, acts of worship in general, or more specifically to the service of priests in the temple. For examples of the oath formula, see b. Yevam. 32b; b. Shabb. 127b; b. Ta'an. 24a; b. Menah. 44a; b. Ber. 34b; b. B. Bat. 11a; b. Zevah. 13a.

62. Soncino, Neusner, and William Davidson.

63. The generations and approximate dates of rabbis quoted in the Tosefta and Talmuds were derived from David Instone-Brewer, Traditions of the Rabbis in the Era of the New Testament Volume 1: Prayer and Agriculture (Grand Rapids: Eerdmans, 2004), 18-27. See also the discussion of the dating of rabbinic traditions on pp. 28-40. 


\begin{tabular}{|c|c|c|c|}
\hline Source & Speaker(s) & Generation & Time period \\
\hline $\begin{array}{l}\text { t. Zebah. 1:8 } \\
=\text { b. Zebah. } 13 \mathrm{a}\end{array}$ & Tarfon & 3rd-generation Tanna & $120-140$ \\
\hline $\begin{array}{l}\text { y. Yevam. } 49 \mathrm{~b} \\
=\text { y. Qidd. } 43 \mathrm{~b}\end{array}$ & Yohanan & $\begin{array}{l}\text { 2nd-generation } \\
\text { Palestinian Amora }\end{array}$ & $250-290$ \\
\hline y. B. Bat. 23b & Eleazar & $\begin{array}{l}\text { 4th-generation Tanna or } \\
\text { 3rd-generation Palestinian } \\
\text { Amora }\end{array}$ & $\begin{array}{l}140-165 \text { or } \\
290-320\end{array}$ \\
\hline b. Ber. $34 \mathrm{~b}$ & Gamaliel & $\begin{array}{l}\text { 1st- or 2nd-generation } \\
\text { Tanna }\end{array}$ & $10-120$ \\
\hline b. Yevam. 32b & $\begin{array}{l}\text { Hiyya } \\
\text { Qappara }\end{array}$ & 6th-generation Tanna & $200-220$ \\
\hline b. Menah. $44 \mathrm{a}$ & Natan & 5th-generation Tanna & $165-200$ \\
\hline b. Shabb. $127 b$ & Anonymous & Tannaitic tradition & Unknown \\
\hline b. B. Bat. 11a & Benjamin the Righteous & Unknown & Unknown \\
\hline
\end{tabular}

After the temple's destruction and the cessation of temple rituals, several aspects of the temple cultus were transferred to acts of personal worship and synagogue practices. Akiva Cohen points out that the opening passage of the Mishnah (m. Ber. 1:1) uses priestly activity in the temple as the template establishing the halakic parameters of Jewish liturgy in that the hours established for the recitation of the Shema corresponded to the former ministry of the priests in the temple. ${ }^{64}$ The Mishnah also set the time for the recitation of the morning and evening communal prayers at the time of temple sacrifices (m. Ber. 4:1) ${ }^{65}$ Cohen argues cogently that both the Mishnah and features of ancient synagogues demonstrate that a 'spatial transference of the temple's sacrality' to the synagogue and Bet Midrash occurred after AD 70. Furthermore, those of the priestly line assumed roles in the synagogue that implied the continuation of their service without the temple proper. ${ }^{66}$ In this context, an oath 'by the service' rather than by the temple itself makes perfect sense. The divine 'service' had endured beyond AD 70, even though the temple had not. ${ }^{67}$

64. Cohen, Matthew and Midrash, 425-427.

65. Cohen, Matthew and Midrash, 428-435.

66. Cohen, Matthew and Midrash, 440-479.

67. This response to the destruction of the temple is reminiscent of the Qumran community's reaction to the perceived defilement of the temple in the second temple 
Apart from quotations of the Mishnaic texts treated above, the Babylonian Talmud does not use the vow formula 'by this temple!' However, Rabbi Yohanan used the formula 'by the Sanctuary!' (היכלא) in b. Qidd. 71a. This Yohanan is Yohanan b. Nappaha, one of the second-generation Amoraim who lived c. AD 190-279 and was traditionally regarded as the scholar primarily responsible for collecting the material that would serve as the foundation for the Jerusalem Talmud. ${ }^{68}$ However, good reasons exist for doubting that the Babylonian Talmud preserves the precise oath formula used by Yohanan. Most importantly, this same statement from Yohanan appears twice in the Jerusalem Talmud (y. Yevam. 49b; y. Qidd. 43b), but both of those texts use the oath formula more common for this period, 'by the [temple] service!' (העבודה). The Jerusalem Talmud probably preserves a more accurate form of Yohanan's original statement. If Yohanan compiled most of the material used in the Jerusalem Talmud, it probably records Yohanan's own statements accurately. ${ }^{69}$ Furthermore, the Jerusalem Talmud predates the Babylonian Talmud by nearly two centuries. ${ }^{70}$ One might expect the Jerusalem Talmud to preserve more accurately the statements of the Palestinian Amoraim due to its closer association with these specific sages. The Babylonian Talmud is clearly the more heavily edited and polished of the two recensions. Finally, the oath formula in b. Qidd. 71a appears to be unique. Although the rabbis of the Mishnah used a similar formula, both the grammar and vocabulary of the early formula are different. Unlike the formula used by the Tannaim, Yohanan's

era. The community saw its own practices as a temporary substitute for the rituals of the temple (1QS III,11; V,6; VIII,10).

68. Alfred Kolatch, Who's Who in the Talmud (New York: Jonathan David, 1964), 232-233.

69. For a helpful introduction to the Jerusalem Talmud and the influence of r. Yohanan on it, see Adin Steinsalt, The Essential Talmud, trans. Chaya Galai (New York: Basic Books, 1976), 48-55. In his introduction to Mishneh Torah, Maimonides stated 'And R. Yohanan wrote the Palestinian Talmud in the land of Israel about three hundred years after the destruction of the temple.' The statement is confused since Yohanan died in AD 279 and since the Jerusalem Talmud describes events and persons of the late fourth century and even early fifth century. Some scholars suggest that the school of Yohanan compiled the Talmud or that Yohanan personally compiled the core of the collection, which was later expanded by others (H. L. Strack and G. Stemberger, Introduction to the Talmud and Midrash, trans. Markus Bockmuehl (Edinburgh: T\&T Clark, 1991), 95, 187-188).

70. The gathering of Galilean amoraic traditions that culminated in the compilation of the Jerusalem Talmud extended from approximately AD 220-425. The Babylonian Talmud was completed in AD 620. See Charlotte Fonrobert and Martin Jafee, eds, The Cambridge Companion to the Talmud and Rabbinic Literature (New York: Cambridge University Press, 2007), xv-xvi, https://doi.org/10.1017/CCOL0521843901. Jacob Neusner dates the Jerusalem Talmud to AD 400 and the Babylonian Talmud to AD 600 (Introduction to Rabbinic Literature, ABRL (New York: Doubleday, 1994), 153). 
formula lacks the demonstrative pronoun. Yohanan also uses a different noun in his oath formula than the one employed three times in the Mishnah (היכלא instead of המעון.). rather than 'by the sanctuary'. It is unclear why the editors of the Babylonian Talmud would have revised the oath formula. In any event, three factors suggest that swearing by the temple became very rare after the temple's destruction: 1) the use of the vow formula invoking the temple three times in the Mishnah by speakers prior to the destruction of the temple; 2) the apparent replacement of the vow formula invoking the temple with one referring to divine worship instead; and 3) the questionable use of a similar formula on only one occasion in the entire Talmud by a figure after the fall of Jerusalem.

\section{Matthew's Purpose for Including Matthew 23:16-22}

This entire discussion is, of course, irrelevant for establishing the date of composition for Matthew if the pericope is a mere example of historicisation. ${ }^{72}$ Perhaps the author recorded the discussion about oath formulas as a sample of Jesus's indictments against the scribes and Pharisees, although he wrote at a time when these specific oath formulas were no longer being used. While this is possible, it seems highly improbable. France's assumption that Matthew likely saw this pericope as 'immediately relevant' for his readers is supported by abundant evidence. ${ }^{73}$

71. Perhaps the change in formula signalled that Yohanan was referring to the heavenly sanctuary rather than a now non-existent earthly one or to a future temple. Some Jews anticipated the rebuilding of the city, the temple, and the altar (m. Ma'as. 5:2; b. Ber. 44a). They also prayed for the rebuilding of the House of God (m. Tamid 7:3; m. Pesah. 10:6; m. Ta'an. 4:8; m. Avot 5:20).

72. David Bauer, The Gospel of the Son of God: An Introduction to Matthew (Downers Grove: IVP Academic, 2019), 85. For his explanation of historicisation, see pp. 60-80. Bauer points to the restriction of Jesus's ministry and that of his disciples to Jews (Matt 15:21-28; 10:56) as a clear example of historicisation since "this restriction was made obsolete with the climactic command to "make disciples of all nations" in the time of the implied reader (Mt 28:18-20)' (p. 72). Although historicisation may be identified confidently in examples like this one, in which the Gospel explicitly qualifies early instruction that does not directly apply to the implied reader, it potentially occurs elsewhere without this clear indication. Bauer rightly notes that this introduces 'an element of tentativeness into our work of reconstructing the original audience addressed in Matthew's composition' (p. 74).

73. France, Matthew: Teacher and Evangelist, 88. 
If Matthew used Mark's Gospel (as most scholars are convinced), comparative analysis shows that he generally shortens Mark's narrative. ${ }^{74}$ This displays a concern for the economy of words, and this suggests that Matthew is not likely to have placed material in his Gospel that was irrelevant to his original readers. The fact that this pericope is unique to Matthew and not derived from a known source suggests that he included it purposefully, presumably because he deemed the material important and somehow applicable to his Jewish Christian readers.

Although redaction critics have sometimes been overconfident in their highly detailed reconstructions of the Sitz im Leben of the Gospel, Graham Stanton correctly stated: 'It is possible to discern from the text of Matthew's Gospel the circumstances of the evangelist's readers. ${ }^{75}$ Matthean scholars generally affirm the view that the Gospel was originally addressed to churches in dialogue or debate with the scribes and Pharisees, the leaders of emergent rabbinic Judaism. Stanton fittingly described the churches for which Matthew originally composed his Gospel as 'minority groups still living in the shadow of thriving local Jewish communities'. ${ }^{76}$ Davies and Allison, borrowing expressions from Stanton, stated that 'in Matthew's situation the synagogue was still across the street, and there was yet competition for adherents'. ${ }^{77}$

Nowhere is this background more prominent in the Gospel of Matthew than in chapter 23. John Kampen has recently presented the case that Matthew is a 'sectarian narrative' that seeks to distinguish the 'practices and ideology of the sect from its Jewish competitors and the dominant culture of that community'. ${ }^{78}$ He observes that Matthew 23 plays a critical role in emphasising the distinct practices of Matthew's sect that set it apart from these competitors:

74. Nolland, Matthew, 10 correctly observed that 'Matthew fairly consistently abbreviates the Markan narrative.'

75. For a helpful affirmation of redaction criticism qualified by important cautions, see Graham Stanton's essay 'Redaction Criticism: The End of an Era?' in A Gospel for a New People: Studies in Matthew (London: T\&T Clark, 1992), 23-53, esp. 45.

76. Stanton, 'Redaction Criticism', 3.

77. Davies and Allison, Matthew, 3:284. See also Ulrich Luz, Matthew, 3 vols, Hermeneia (Minneapolis: Fortress, 2001-2007), 3:170-173. One must, of course, distinguish between the Sitz im Leben of the discourse and the Sitz im Leben of the Gospel if the discourse is not Matthew's creation. Kenneth Newport has persuasively argued that the original Sitz im Leben of Matt 23 is one of intramural disputes in Judaism prior to AD 70. See his The Sources and Sitz im Leben of Matthew 23, 61-156.

78. John Kampen, Matthew within Sectarian Judaism, AYBRL (New Haven: Yale University, 2019), 208-209. For a similar view, see Matthias Konradt, The Gospel According to Matthew: A Commentary, trans. Eugene Boring (Waco: Baylor, 2020), 18-20. 
The tension between Jesus and the Pharisees escalates with his diatribe of Matthew 23. These conflicts are the manner in which Matthew has chosen to articulate his understanding of the relationship between the sectarian followers of Jesus and the remainder of the Jewish community, including the various segments and leadership groups within it. In the case of Matthew 23 we find the Pharisees depicted as the counterexample to the followers of Jesus whose sectarian practices and rationale have been advanced in the Sermon on the Mount. ${ }^{79}$

The historical setting of tension between Matthew's community and the local Jewish community is important for understanding Matthew's motive for including Matthew 23 and particularly 23:16-22.

Some scholars have argued that the primary purpose of Matthew 23 is 'pedagogical', that is, the discourse is intended to use the scribes and Pharisees as 'forbidding examples of sins that are a present danger to disciples' ${ }^{80}$ This suggestion is clearly true for at least some portions of the discourse since Jesus explicitly warned his disciples 'Don't do what they do' (23:3). However, some portions of the discourse appear to be more polemical than pedagogical, and verses 16-22 certainly belong to this polemical category. ${ }^{81}$ Matthew clearly does not include the discussion of binding and non-binding oaths to guide the oathtaking of the disciples in the communities that he addressed. Jesus had already clearly prohibited the use of all oaths in ordinary daily life in Matthew 5:33-37, and Matthew expects his readers to obey Jesus's teaching on this matter. This suggests that Matthew includes the discussion in 23:16-22 because the casuistry related to the oaths still characterised Jewish opponents of Matthew's community, and Matthew wanted his readers to see the flaws in their moral reasoning. In other words, Matthew 23 not only preserves Jesus's prophetic rebuke of the Pharisees and scribes but also serves as Matthew's polemic against the synagogue members that have rejected Jesus's message.

The argument made by Jesus supposes that the temple is so closely associated with the God who dwells in it that the temple may serve as a valid substitution for the divine name in an oath formula. If opponents of Matthew's community

79. Kampen, Matthew within Sectarian Judaism, 208.

80. David Garland, Reading Matthew: A Literary and Theological Commentary (Macon, GA: Smyth \& Helwys, 2001), 233. See also Garland's The Intention of Matthew 23, 37-41, 61-63.

81. Luz goes so far as to say 'With the exception of vv. 8-12, however, our chapter has only marginally "a pedagogical function".' He argues that the primary purpose of the discourse is to provide 'legitimacy for the separation of the church from the synagogues'. Through this discourse, Matthew 'polemicized against Israel and its leaders in the name of Israel's Messiah'. See his Matthew, 3:170-173. 
rejected this argument, it would appear that Jesus (and the Matthean community) had a higher view of the Jerusalem temple than the scribes and Pharisees (and the opponents of the Matthean community) who, ironically, condemned him and his followers in part for having too low a view of the temple (Matt 26:60-62; Acts $6: 13-14 ; 21: 28)$. Thus, Jesus's polemic was a powerful one with which the local synagogue members would be compelled to agree.

However, if the Jewish opponents of Matthew's churches no longer used these oaths or made the fine distinctions described in 23:16-22, the polemic would lose its force. Matthew's readers might reply dismissively that the leaders of the synagogues no longer used such formulas and thus were not guilty of the hairsplitting that characterised earlier generations of rabbis. In such circumstances, one would expect Matthew to recognise that this discussion would only be counterproductive in his polemic and to choose to omit it. Thus Matthew's inclusion of this pericope makes the most sense in a historical context in which the oath formulas were still being used by members of local synagogues and the validity of oath formulas in which one swore by the temple or its sanctified items remained a topic of interest to Matthew's original readers and their Jewish dialogue partners.

\section{Conclusion}

The issues surrounding the date of composition for Matthew's Gospel are complex, too complex to allow hard-and-fast conclusions. Nevertheless, the oath formulas of Matthew 23:16-22 seem to support a date of composition earlier than the date currently affirmed by the majority of scholars. The oath formulas in the Mishnah, Tosefta, Jerusalem Talmud, and Babylonian Talmud suggest that swearing by the temple was relatively common prior to the destruction of the temple, but very rare thereafter. Matthew probably sought to use Matthew 23:16-22 as part of a polemic against the practices of synagogues that were opposing their contemporaries who followed Jesus. Yet this polemic related to the vow formulas would have been ineffective and possibly even counterproductive if relating only to outdated practices that were no longer relevant after the destruction of the temple. Thus, the appeal to the oath formulas of Matthew 23:16-22 as evidence that Matthew was composed while the temple was still standing is a valid argument that coalesces with other lines of evidence for a pre-70 date of composition for the Gospel of Matthew. 


\section{Bibliography}

Bauer, David. The Gospel of the Son of God: An Introduction to Matthew. Downers Grove, IL: IVP Academic, 2019.

Ben-David, Arye.Jerusalemund Tyros. Ein Beitrag zurpalästinischen Münz-und Wirtschaftsgeschichte (126 a.C.-37 p.C). Basel: Mohr, 1969.

Blomberg, Craig. Matthew. NAC. Nashville: Broadman, 1992.

Carson, D. A. 'Matthew'. Pages 1-599 in Matthew and Mark. Rev. ed. Expositor's Bible Commentary 9. Grand Rapids: Zondervan, 2010.

Cohen, Akiva. Matthew and the Mishnah: Redefining Identity and Ethos in the Shadow of the Second Temple's Destruction. WUNT 418. Tübingen: Mohr Siebeck, 2016. https://doi. org/10.1628/978-3-16-154810-9.

—. 'Matthew and the Temple'. Pages 75-100 in Matthew within Judaism: Israel and the Nations in the First Gospel. Edited by Anders Runesson and Daniel Gurtner. ECL 27. Atlanta: SBL, 2020. https://doi.org/10.2307/j.ctv13qfv9z.8.

Conklin, Blane. Oath Formulas in Biblical Hebrew. LSAWS 5. Winona Lake, IN: Eisenbrauns, 2011. https://doi.org/10.5325/j.ctv1bxgzws.

Danby, Herbert. The Mishnah. Oxford: Oxford University Press, 1933.

Davies, W. D. and Dale Allison. Matthew. 3 vols. ICC. Edinburgh: T\&T Clark, 1988-1997.

Epstein, Isidore et al., eds. Soncino Hebrew-English Talmud. 18 vols. London: Soncino, 19651989.

Evans, Craig. Matthew. New Cambridge Bible Commentary. New York: Cambridge University Press, 2012.

Fonrobert, Charlotte and Martin Jafee, eds. The Cambridge Companion to the Talmud and Rabbinic Literature. New York: Cambridge University Press, 2007. https://doi.org/10.1017/ CCOL0521843901.

France, R. T. Matthew: Teacher and Evangelist. Downers Grove, IL: IVP, 1980.

- The Gospel of Matthew. NICNT. Grand Rapids: Eerdmans, 2007.

Garland, David. The Intention of Matthew 23. NovTSup 51. Leiden: Brill, 1979. https://doi. org/10.1163/9789004266636.

- Reading Matthew: A Literary and Theological Commentary. Macon, GA: Smyth \& Helwys, 2001.

Gibbs, Jeffrey. Matthew 1:1-11:1. Concordia Commentary. St Louis: Concordia, 2006.

Gundry, Robert. Matthew: A Commentary on His Handbook for a Mixed Church under Persecution. 2nd ed. Grand Rapids: Eerdmans, 1994.

Gurtner, Daniel. 'Matthew's Theology of the Temple and the "Parting of the Ways": Christian Origins of the First Gospel'. Pages 128-153 in Built upon the Rock: Studies in the Gospel of Matthew. Edited by Daniel Gurtner and John Nolland. Grand Rapids: Eerdmans, 2008.

Hagner, Donald. Matthew 1-13. WBC 33a. Dallas: Word, 1993.

Instone-Brewer, David. Traditions of the Rabbis in the Era of the New Testament Volume 1: Prayer and Agriculture. Grand Rapids: Eerdmans, 2004.

—. 'Qorban in Mat. 23.16-20 \& m. Ned. 1.3'. Rabbinic Traditions. https://rabbinictraditions. blogspot.com/2020/11/qorban-in-mat2316-20-mned13.html.

Jastrow, Morris, comp. A Dictionary of the Targumim, the Talmud Babli and Yerushalmi, and the Midrashic Literature with an Index of Scriptural Quotations. London: Luzac; New York: G. P. Putnam's Sons, 1903.

Kampen, John. Matthew within Sectarian Judaism. AYBRL. New Haven: Yale University Press, 2019. 
Keener, Craig. A Commentary on the Gospel of Matthew. Grand Rapids: Eerdmans, 1999.

Kolatch, Alfred. Who's Who in the Talmud. New York: Jonathan David, 1964.

Konradt, Matthias. The Gospel According to Matthew: A Commentary. Translated by Eugene Boring. Waco: Baylor, 2020.

Liddell, Henry George, Robert Scott, and Henry Stuart Jones. A Greek-English Lexicon. 9th ed. with revised supplement. Oxford: Clarendon, 1996.

Lieberman, Saul. Greek in Jewish Palestine: Studies in the Life and Manners of Jewish Palestine in the II-IV Centuries CE. New York: Jewish Theological Seminary of America, 1942.

Luz, Ulrich. Matthew. 3 vols. Hermeneia. Minneapolis: Fortress, 2001-2007.

Maier, Gerhard. Das Evangelium des Matthäus: Kapitel 1-14. HTA. Witten: SCM, 2015.

Murphy-O'Connor, Jerome. 'Jesus and the Money Changers (Mark 11:15-17; John 2:13-17)'. RB 107 (2000): 42-55.

Neusner, Jacob. Introducing Rabbinic Literature. ABRL; New York: Doubleday, 1994.

- The Babylonian Talmud: A Translation and Commentary. 22 vols. Peabody, MA: Hendrickson, 2011.

Newport, Kenneth. The Sources and Sitz im Leben of Matthew 23. JSNTSup 117. Sheffield: Sheffield Academic, 1995.

Nolland, John. The Gospel of Matthew. NIGTC. Grand Rapids: Eerdmans, 2005.

Osborne, Grant. Matthew. Exegetical Commentary on the New Testament. Grand Rapids: Zondervan, 2010.

Quarles, Charles. Matthew. Exegetical Guide to the Greek New Testament. Nashville: B\&H, 2017.

Richardson, Peter. 'Why Turn the Tables? Jesus' Protest in the Temple Precincts'. Pages 507523 in Society of Biblical Literature 2001 Seminar Papers. SBLSP 31. Atlanta: Scholars Press, 1991.

Robinson, J. A. T. Redating the New Testament. London: SCM, 1976.

Sefaria. The William Davidson Talmud. https://www.sefaria.org/texts/Talmud. 2017.

Stanton, Graham. 'Redaction Criticism: The End of an Era?' Pages 23-53 in A Gospel for a New People: Studies in Matthew. London: T\&T Clark, 1992.

Steinsalt, Adin. The Essential Talmud. Translated by Chaya Galai. New York: Basic Books, 1976. Strack, H. L. and G. Stemberger. Introduction to the Talmud and Midrash. Translated by Markus Bockmuehl. Edinburgh: T\&T Clark, 1991.

Urbach, Ephraim. The Sages: Their Concepts and Beliefs. 2 vols. Jerusalem: Magnes, 1987.

Ziegler, Yael. 'So Shall God Do: Variants of an Oath Formula and Its Literary Meaning'. JBL 126 (2007): 59-81. https://doi.org/10.2307/27638420. 